\title{
22q Telomere Deletion Syndrome
}

National Cancer Institute

\section{Source}

National Cancer Institute. 22q Telomere Deletion Syndrome. NCI Thesaurus. Code C75478.

A genetic syndrome caused by terminal $22 q 13$ microdeletions. It is characterized by developmental delay and delayed or absent speech. 